\title{
MOOCS AS A TOOL FOR VIRTUAL UNIVERSITY ORIENTATION
}

\author{
Ilaria Merciai, \& Ruth Kerr \\ Federica Web Learning, Centre for Innovation, Experimentation and Diffusion of Multimedia Learning, \\ University of Naples Federico II (Italy)
}

\begin{abstract}
The Covid-19 era, and its enforced transition of all teaching and learning activity to the online space, is potentially leading to reduced university enrolment rates. International student enrolments are predictably down due to travel restrictions and concerns about student safety, but even at home the same trends are being observed. One of the conversations around this issue is the value-for-money question in relation to a perceived reduction in the quality of the overall student experience when the networking opportunities of on-campus life and study are taken away. A further question is the level of digital readiness of staff and school-leaver students, and whether they are able to deal successfully with preparation for final-year school exams, university choice, and for university entrance tests in remote learning. Federica Web Learning, the University Centre for Research Innovation and Dissemination of multimedia and distance learning, has long been making the case for MOOCs as a valid tool for virtual orientation. In the current climate, MOOCs can provide chunks of ready-made quality learning content for use as the asynchronous component in today's hybrid online courses, meaning that the time teacher and class spend in plenary, in video-conferencing, can be devoted to discussion and more in-depth analysis of the learning objectives. The MOOCs can be specially chosen from the growing range on offer from university providers around the world: some provide remedial content in problem subjects and topics; some offer specific exam preparation content and others offer university orientation, or study skills.
\end{abstract}

Keywords: MOOCs, university entrance, hybrid models, digital readiness.

\section{Introduction}

2020 has been dubbed the second year of the MOOC $^{1}$. When 150 million learners were forced online due When 150 million learners were forced online due to the global pandemic from March 2020 onwards, the major MOOC providers saw a massive surge in user numbers across the board, registering an overall increase of over 110 million enrolments, 35 million of which went to Coursera (Shah D., 2020). Federica Web Learning, with its federica.eu platform ${ }^{2}$, was no exception, registering an average of 330 new users every day in 2020, and a $300 \%$ increase compared to the previous year. By the end of 2020 , according to Class Central (Shah D., 2020) there were 16,000 MOOCs from 950 universities, covering subjects in 13 broad disciplinary areas, but the in-demand skills relating to technology and business still represented $40 \%$ of all courses. The disciplines that enjoyed the biggest increase during the pandemic were personal development, health and medicine, especially information relating to COVID-19, and foreign languages (Shah D., 2020). The message from Providers like Futurelearn ${ }^{3}$ and LinkedIN Learning (McKeever, 2020) was that online learning represented an advantageous use of free time during the lockdown, and when furloughed, in terms of personal growth and learning new skills in readiness for a return to work (Coughlan, 2020). However, in countries with a large, existing MOOC offer, and national governance, like China for example, MOOCs played a significant role in an institutionalised transition to remote learning, for schools as well as universities (McAleavy, Gorgen, 2020). The courses were used countrywide as quality interactive content within a video-conferencing live session framework, or as asynchronous content in an online flipped classroom delivery mode. The major MOOC providers, like

\footnotetext{
${ }^{1}$ https://www.classcentral.com/report/the-second-year-of-the-mooc

${ }^{2} \mathrm{https}: / / \mathrm{www}$. federica.eu

${ }^{3}$ https://www.futurelearn.com/courses/collections/boredom-busters
} 
Coursera $^{4}$, edX $\mathrm{X}^{5}$ and Futurelearn, encouraged this type of MOOC use through various initiatives, including discounted access, free certification and special for-credit schemes with partnering institutions. Although high school teachers and students may well have been part of the growing MOOC audience in this period, there are very few figures available that attest to the precise learner demographic. Specific examples that we have include the preparatory mathematics course on the federica.eu platform ${ }^{6}$, which is designed to aid students in their evaluation of the appropriateness of different degree courses and, more specifically, to support preparation for university entrance tests. This course saw an increase of 25,000 new enrolments on the pandemic edition.

\section{Existing MOOC orientation initiatives}

In a period of forced distance learning, it could be imagined that the orientation process of choosing the right degree subject at the right university, which requires high levels of self-awareness as well as good search skills to find the available choices, is even more complex for school-leavers when they lack the in-person support of their teachers and peers. However, MOOC initiatives that specifically aim to support students in bridging this school to university gap, are still relatively few. The FUN platform published a new cluster of 25 orientation MOOCs from "Is this faculty for me?" and "How to adapt successfully to University Study" to "Careers in Cultural Heritage". Futurelearn also offers courses in the university application process in the UK and "Getting ready for academic success". The Federica Web Learning metaMOOC initiative is one of the few to provide comprehensive access to the classrooms of degree courses in 12 disciplinary areas, offering a general overview of subject matter, level of difficulty, and an insight into the specific teaching style. Across the globe, HE Institutions have launched various initiatives to "weather the recruitment crisis" (Basken et al., 2020), especially where international student fees are an important segment of the funding. In Italy, where enrollment numbers for 2020 were higher than expected but saw students applying to institutions close to home (Vatalaro, 2020) - to reduce costs and for personal safety - a growing number of online Orientation Days and Webinars in 2020 have tended to promote the single institution rather than objectively support students in their university choice or preparation. In line with providing this support, Federica Web learning has established a navigation button on its home page - one of only three specific areas - to target the Orientation audience directly and to guide them to the content specifically developed with their needs in mind.

\section{Society needs skilled citizens}

In an epoch in which the need for a broad range of high-level skills is required by a digital knowledge society and the jobs market, the need for a minimum Bachelor's credential is equally high (Selingo, 2014, 2017). This is especially true in Italy, where the figures regarding numbers of graduates and numbers of NEETS ${ }^{7}$ (OECD, 2020) - compare unfavourably with the rest of Europe. This coincides with a period marked by decreasing student enrolment rates, both internationally and at home. Both factors serve to highlight the potential usefulness of an increased specific online offer for orientation.

A further relevant consideration is the growing body of literature that points to the fact that online and varied forms of hybrid (Perez-Sanagustin et al., 2017) and hyflex (Beatty, 2019) learning are here to stay. Despite problems like the digital divide, and a certain lack of digital preparation on the part of some teachers, recent surveys, including our own - jointly created and administered by IPSOS Italy and Federica Web Learning (Reda, 2020), and targeting 1200 university students throughout Italy - highlight the advantages of quality online learning, in terms of flexibility, inclusion, greater opportunities for personalised and community learning from a student perspective, and cost-effectiveness, scalability and research-based provision, from an institutional perspective. The offer of a well-managed digital infrastructure that covers all aspects of student life from orientation to exams, from learning to mentoring and counselling will probably be increasingly important to tomorrow's students.

\footnotetext{
${ }^{4}$ https://blog.coursera.org/coursera-together-free-online-learning-during-covid-19

${ }^{5} \mathrm{https}: / /$ www.edx.org/covid-19

${ }^{6} \mathrm{https}: / / \mathrm{ms}$.federica.eu/enrol/index.php?id=3

${ }^{7}$ In Italy a national plan proposal "Memoria del Ministro Franco sulla Proposta di piano nazionale di ripresa e resilienza [Commissioni congiunte 5a, 6a e 14a Senato della Repubblica V, VI e XIV Camera dei deputati] - 08 marzo 2021" has been disseminated. Retrieved from: https://www.mef.gov.it/ufficio-stampa/articoli/2021_2023-Daniele_Franco/Audizione-del-Ministro-Franco-sulla-Proposta-dipiano-nazionale-di-ripresa-e-resilienza-Commissioni-congiunte-5a-6a-e-14a-Senato-della-Repubblica-V-VI-e-XIV-Camera-deideputati-08-marzo-2021/
} 


\section{Conclusion}

The effectiveness of a MOOC based orientation strategy was already explored in our previous contributions (Merciai, Kerr, 2019; Merciai, Kerr, Melchionna, 2021), where we set out the three-pronged strategy that Federica Web Learning now employs: a classic orientation based on clarification of content and method for specific degree courses; academic preparation for university entrance exams; vocational preparation aimed at raising self-awareness to manage the changes that the move from school to university represent.

The pandemic forced educational institutions to deliver their teaching and learning in remote, and those institutions who already had online courses, digital content or structured learning pathways available, as well as staff with experience of multimedia delivery, were obviously in a better position to deal with the physical closure of schools and campuses. And this is true for the stages of student orientation too. As various forms of hybrid learning look set to remain, post-covid, it is important that guidance for final-year school exams, university choice, and for university entrance tests succeed in a digital learning format too, so that growing numbers of school-leavers not only enroll on the university degree courses that society needs, but also stay the course and graduate successfully.

\section{References}

Basken P., Bothwell E., McKie A., Matthews D., Ross J. (2020). Which nations will weather the storm on international recruitment? Five key recruiting nations' crisis measures on international student recruitment compared and analysed. Retrieved February 25, 2021 from https://www.timeshighereducation.com/news/which-nations-will-weather-storm-internationalrecruitment

Beatty B. J. (2019). Hybrid-Flexible Course Design, EdTech Books. Retrieved February 25, 2021 from https://edtechbooks.org/hyflex

Coughlan S. (2020) Coronavirus: Furloughed workers offered online skills training. Retrieved February 25, 2021 from https://www.bbc.com/news/education-52447539

J.J. Selingo J. J. (2017). The Future of the Degree: How Colleges Can Survive the New Credential Economy, in The Chronicle of Higher Education Special Report, Washington D.C., The Chronicle of Higher Education.

McAleavy T., Gorgen K. (2020) Education Development Trust. Retrieved February 25, 2021 from https://edtechhub.org/wp-content/uploads/2020/04/research-best-practice-pedagogy-remoteteaching.pdf

McKeever V. (2020). Not working due to lockdown? Here's how to keep busy and learn new skills. Retrieved February 25, 2021 from https://www.cnbc.com/2020/04/08/coronavirus-heres-how-tokeep-busy-and-learn-new-skills-on-furlough.html

Merciai I., Kerr R. (2019). MOOCs as a Key Strategy for University Orientation in Education and New Developments 2019, ISSN: 2184-044X ISBN: 978-989-54312-5-0 2019, pp. 286-90.

Merciai I., Kerr R., Melchionna G. (2021), Moocs For Bridging The School - University Gap, in Education Applications \& Developments VI. Being printed.

OECD. (2020). Education at a Glance. Retrieved February 25, 2021 from https://www.oecd.org/education/education-at-a-glance

OECD. (2020). OECD Employment Outlook 2020. Worker Security and the Covid-19 Crisis. How does Italy Compare. Retrieved February 25, 2021 from https://www.oecd.org/italy/EmploymentOutlook-Italy-EN.pdf

Perez-Sanagustin M., Hilliger I., Alario-Hoyos C., Delgado Kloos C., Rayyan S. (2017) H-MOOC framework: reusing MOOCs for hybrid education, in « Journal of Computing in Higher Education », 29, pp. 47-64.

ProjetSUP on FUN platform. Retrieved February 25, 2021 from https://www.mooc-orientation.fr and https://www.fun-mooc.fr/news/25-mooc-dorientation-sont-disponibles-sur-fun

Reda V. (2020). Generazione Greta. In De Notaris D., Melchionna G., Reda V. (a cura di). (2020) Didattica digitale. Chi, come e perché. Salerno editore. ISBN: 8869735354, p. 136.

Shah D. (2020). By the Numbers: MOOCs During the Pandemic. Retrieved February 25, 2021 from https://www.classcentral.com/report/mooc-stats-pandemic

Vatalaro F. (2021). Università, le previsioni erano nere come la pece. Ma forse le cose non vanno poi così male. Retrieved February 25, 2021 from https:/www.ilfattoquotidiano.it/2020/09/15/universita-leprevisioni-erano-nere-come-la-pece-ma-forse-le-cose-non-vanno-poi-cosi-male/5930702/ 